\title{
KEYBOARD INSTRUMENTS AND INSTRUMENTALISTS IN MANILA (1581-1798)
}

David IRVING

\begin{abstract}
While countless keyboard instruments were made in the Philippine Islands or imported there during the Spanish colonial period (1565-1898), most of those which survive date from the nineteenth century. It should be noted, however, that keyboard music flourished in the Philippines from the early years of Spanish presence. Instruments began to arrive in the late-sixteenth century, and over the following two centuries, numerous organs were manufactured in mission schools throughout the archipelago. The final years of the eighteenth century were a high point in colonial instrument-building, moreover, with the arrival of the Recollect missionary and instrument-builder Diego Cera de la Virgen del Carmen in 1792 and the establishment of his workshop. While some evidence remains fragmentary, there is still a great deal of archival information to be pieced together, and a comprehensive survey of keyboard instruments and instrumentalists present in colonial Manila remains to be undertaken. This article attempts to address this lacuna in part, covering the period between 1581 and 1798 .
\end{abstract}

\section{Resumen}

Aunque muchos instrumentos de teclado fueron fabricados en las Filipinas o importados por aquellas islas durante el período colonial español (1565-1878), la mayor parte de los que aún existen son del siglo XIX. Debe tenerse en cuenta, sin embargo, que la música para teclado tuvo un auge importante en Filipinas desde los inicios mismos de la presencia española. Empezaron a llegar diversos instrumentos hacia finales del siglo XVI, y a lo largo de los dos siglos siguientes se construyeron varios órganos en las escuelas de las misiones presentes en el archipiélago. Al final del siglo XVIII muchos instrumentos fueron construidos en las colonias, sobretodo con la llegada del misionero y constructor de instrumentos, Diego Cera de la Virgen en el año 1792, y el establecimiento de su taller. Aunque sólo disponemos de una información incompleta, aún existe mucha información de archivo a la espera de ser reunida, y todavía hace falta realizar un estudio detallado de los instrumentos de teclado y de sus ejecutantes durante aquel periodo colonial en Manila. Este artículo pretende cubrir esta laguna en parte, referida al período 1581 a 1798.

From the early sixteenth century, keyboard instruments were commonly taken by European expeditions to the Orient as diplomatic gifts or bribes for local rulers. ${ }^{1}$ A harpsichord or clavichord was a suitable gift for dignitaries, as it not only could be decorated splendidly, but it also demonstrated "European artistry, craftmanship and mechanical ingenuity," was not overly expensive, and could be easily transported. ${ }^{2}$ The presence of such instruments also facilitated the work of missionaries in Asia, as a clavichord or organ could be used both in a diplomatic performance as well

1. See Ian Woodfield, "The Keyboard Recital in Oriental Diplomacy, 1520-1620," Journal of the Royal Musical Association 115.1 (1990): 33-62.

2. Ibid., 33 .

Anuario Musical, 60 (2005) 
as in worship. While these instruments were frequently presented formally to courts and imported for missionary use in India, China and Japan, ${ }^{3}$ the nation in which they enjoyed the most significant and continuous exposure in this region was undoubtedly the Philippines. As this archipelago of more than seven thousand islands was subject to conquest rather than diplomatic exchange, however, keyboard instruments were present there in very different circumstances to most of Asia, and generally followed the pattern of Latin America in terms of prevailing tastes and priorities in colonial music culture.

Founded by the conquistador Miguel López de Legazpi in 1571, the "Very Noble and Ever Loyal" city of Manila was the heart of Spanish mercantile, diplomatic, religious and socio-cultural enterprises in Asia until 1898, when the Philippine Islands were annexed by the United States. Intramuros, the fortified city centre of Manila, occupies a unique place in South-East Asia, as no other major European city has been established in the region with such a concentration of churches, monasteries, schools, hospitals, universities and government buildings within so limited a space. Prior to its almost complete destruction in 1945, foreign visitors to Intramuros often remarked on the abundance of churches, one noting in 1906 that the exact number of sanctuaries and chapels was almost impossible to determine. ${ }^{4}$ The Dominican historian Fidel Villarroel has even gone so far to suggest, quite justifiably, that "meter for meter, foot for foot, perhaps no single city in the whole Christian world had so much religious ground space [as] Old Manila."5

Not surprisingly, sacred and secular music was an essential part of daily life in Manila, in Intramuros and the surrounding suburbs. In the early days of the colony, as wave upon wave of imported European musical instruments arrived in the Philippines (mostly via Mexico and the transPacific galleons), organs figured prominently as they were brought to be installed in newlyestablished churches and cathedrals. As immigrant craftsmen arrived and as the need for new instruments grew, a thriving local trade arose, although the importation of new organs and of technical innovations did not cease. Together with the rise of personal and institutional wealth in Manila, there probably also arose an increased need for domestic keyboard instruments, especially in the eighteenth century.

Most of the Spanish-period keyboard instruments that survive in the Philippines today date from the nineteenth century. The most notable example is the bamboo organ of Las Piñas, built by the Recollect missionary Diego Cera from 1816 to 1821 . These extant instruments have received due attention from performers and scholars alike in recent times, ${ }^{6}$ with some having been carefully

3. See respectively ibid., 34-5; Joyce Z. Lindorff, "The Harpsichord and Clavichord in China during the Ming and Qing Dynasties," Early Keyboard Studies Newsletter VIII.4 (1994): 1; Eta Harich-Schneider, A History of Japanese Music (London: Oxford University Press, 1973), 466-7, 471.

4. George A. Miller, Interesting Manila, 2nd ed. (Manila: E. C. McCullough \& Co., Inc., 1906), 79.

5. Fidel Villarroel, O.P., "Implications of the Religious Festival in Intramuros", Intramuros and Beyond (Manila: Letran College, 1975), 46.

6. See the excellent study by Hans Gerd Klais and Hans Steinhaus, The Bamboo Organ in the Catholic Parish Church of St. Joseph at Las Piñas, Province of Rizal on the Island of Luzon, Philippines, trans. Homer D. Blanchard (Delaware, Ohio: Praestant Press, 1977). Klais restored the Bamboo Organ from 1972 to 1975. See also Helen F. Samson, The Bamboo Organ of Las Piñas (Las Piñas: Parish of St. Joseph, 1977).

28

(c) Consejo Superior de Investigaciones Científicas Licencia Creative Commons 3.0 España (by-nc)
Anuario Musical, 60 (2005)

http://anuariomusical.revistas.csic.es 
restored. While documentary evidence from prior to 1800 remains fragmentary, with the destruction of so many religious archives in the liberation of Manila in 1945, there is a great deal of archival information to be pieced together, and a comprehensive chronological survey of keyboard instruments and instrumentalists in Manila remains to be undertaken. This article attempts to address this lacuna in part, and intends to give an overview of the main figures and events involved in the introduction and development of keyboard instruments in the royal city of Manila, from its foundation in 1571 to the end of the eighteenth century.

Although small keyboard instruments may have made their way to Manila soon after the conquistadores settled there in 1571 , the earliest documentary evidence of their introduction comes from 1581, the year of the arrival of Domingo de Salazar, O.P., the first bishop of the Philippines. He set out immediately to establish the first Cathedral of Manila, dedicated to the Immaculate Conception. Although this was a temporary structure built from nipa palm and bamboo, the Mass and Offices were celebrated with full dignity, for Salazar had not come unprepared. ${ }^{7}$ He had brought with him his personal library, which included "12 misales, 4 libros de canto, 12 libros yntonatorios $y$ procesonarios", among other items, ${ }^{8}$ as well as recorders and shawms, and a pipe organ. These had been bought in Spain and New Spain out of a budget of 2000 pesos for the purchase of all materials which Salazar believed necessary for the proper functioning of a cathedral. ${ }^{9}$ The document concerning the erection of Manila Cathedral states quite simply that "[t]he duty of [the] organist is to play on feast days and at other times at the direction of the chapter." 10 The annual salary of the organist was listed as sixteen pesos. ${ }^{11}$ Within the first year of its foundation, a choir of men and boys was established in the cathedral, and from at least 1582 this choir performed polyphonic music for solemn masses, accompanied by wind instruments and organ, under the direction of the Chantre Francisco de Morales, a secular priest. ${ }^{12}$ On 18 June, 1583, Salazar wrote to Philip II that

[c]on los muchachos del coro y otros que savian musica y con los organos y flautas y chirimias que conmigo traje celebravase el oficio divino en las fiestas como se pudieran celebrar en otra yglesia catedral mas antigua y mas rica que esta. ${ }^{13}$

... With the boys of the choir, and others who knew music, and with the organs and flutes and shawms which I brought with me, the divine office was celebrated on feastdays as it could be celebrated in another cathedral more ancient and richer than this one.

7. William John Summers, "Listening for Historic Manila: Music and Rejoicing in an International City," Budhi: A Journal of Ideas and Culture 2.1 (1998): 209.

8. Robert William Harold Castleton, “The Life and Works of Domingo de Salazar, O.P. (1512-1594)," Unpublished Ph.D. Thesis, University of London, 1974, 288, 306.

9. Ibid., 306.

10. Domingo de Salazar, O.P., "Erection of the Manila Cathedral," The Philippine Islands, 1493-1898, ed. James A. Robertson, vol. 34 (Cleveland: Arthur H. Clark Co., 1903-09), 344.

11. Ibid., 347.

12. Castleton, 67; William John Summers, "The Jesuits in Manila, 1581-1621: The Role of Music in Rite, Ritual and Spectacle," The Jesuits: Culture, Learning and the Arts, 1540-1773, ed. John W. O'Malley (Toronto: University of Toronto Press, 1999), 660.

13. In Castleton, 67. 
Sadly, a fire ripped through the city later that year, burning down the temporary Cathedral, which was built of nipa palm and bamboo, as well as destroying the pipe organ and some, if not all, of the music books brought by Salazar in $1581 .{ }^{14}$

While this material loss was unfortunate, to say the least, the departure of the chantre Morales in 1584 and of Salazar in 1591 caused significant disruption to the cultivation of music in Manila. ${ }^{15}$ The capilla of the cathedral seems to have continued ably under the direction of later musicians, however, according to the report of Dr. Antonio de Morga, who was in Manila from June 1595 to July 1603 (first as Lieutenant-Governor, then as oidor of the Audiencia). ${ }^{16} \mathrm{He}$ recounted in his Sucesos de las Islas Filipinas (Mexico, 1609) that the second cathedral was "furnished with an organ, lecterns, and all other requisite items,"17 had a choir, and that the Divine Offices were celebrated there with proper solemnity and ceremony. ${ }^{18}$ This second cathedral, built of stone, was later destroyed by earthquake damage in 1600.

In the final years of the sixteenth century, rumours of organs with bamboo pipes were emanating from Japan. Ruis Mendes, a Portuguese captain who visited Japan in 1596, reported this, and "when he insisted on seeing, touching and hearing one for himself, he could not contain his astonishment." 19 Additionally, "[Japanese] lay catechists (dojuku) at Amakusa ... built several beautiful-sounding bamboo organs, with which the principal churches were equipped", according to a Jesuit Relation dating from $1600 .{ }^{20}$ This is especially significant, as two Franciscan missionaries who were pioneers of music pedagogy in the Philippines later travelled to Japan. The first was St. Pedro Bautista (eventually the leader of the twenty-six martyrs of Nagasaki), whose first task upon arrival in Manila was to teach music to the Tagalogs. After being appointed Custodian and Superior of the Franciscan province of the Philippines in $1586,{ }^{21}$ he proceeded to organise with Fray Jerómino de Aguilar "an integrated course of musical teaching and training, and started a factory of rudimentary musical instruments. In the grand [stone] church of Lumbang [Laguna province] ... Fray Pedro ordered established in 1590 what must be considered the first Academy of Music in the Philippines."22 In 1593, he was sent as an ambassador to Japan, where he was martyred in 1597.

While there is no evidence of organs being constructed in the "academy" at this early time, it is possible that instruction in this art was given by the Franciscan Juan de Santa Marta, who arrived in Manila in 1606 and immediately was entrusted to direct, with fellow Franciscan Juan de Garovillas,

14. Vicente S. Hernández, History of Books and Libraries in the Philippines: 1521-1900 (Manila: The National Commission for Culture and the Arts, 1996), 110; Castleton, 68.

15. Summers, "The Jesuits in Manila, 1581-1621," 662.

16. Antonio de Morga, Sucesos de las Islas Filipinas, trans. J. S. Cummins, Works issued by the Hakluyt Society; 2nd series, no. 140 (Cambridge: Cambridge University Press, 1971), 3-9.

17. Ibid., 284.

18. Ibid., 287.

19. David B. Waterhouse, "Southern Barbarian Music in Japan," Portugal and the World: The Encounter of Cultures in Music, ed. Salwa El-Shawan Castelo-Branco (Lisbon: Publicações Dom Quixote, 1997), 365.

20. In ibid.

21. Eusebio Gómez Platero, Catálogo Biográfico de los Religiosos Franciscanos de la Provincia de San Gregorio Magno de Filipinas desde 1577 en que llegaron los primeros á Manila hasta los de nuestros días (Manila: Imprenta del Real Colegio de Santo Tomás, á cargo de D. Gervasio Memije, 1880), 56.

22. Jesús Ma Merino Antolínez, O.P., "San Pedro Bautista: Philippine Benefactor," San Pedro Bautista: A Saint in the Philippines (Quezon City: Devotees of San Pedro Bautista, 1982), 29. 
the same school in Lumbang. According to numerous sources, four hundred boys from different provinces were brought to this seminary, were taught music [solfa], were trained to sing plainchant and polyphony, and to play and manufacture musical instruments (including wind instruments and pipe organs), then were returned to their home towns where they taught others. ${ }^{23}$

Santa Marta can have done no more than instigate this regime, however, as he travelled to Japan in 1607, becoming head of the Franciscan mission there. He undertook similar pedagogical work, including the teaching of instrument-building, and was noted for his construction of organs. Dorotheus Schilling writes that "[t]he Franciscan Juan de Santa Martha [sic], a superior musician, ... manufactured organs and other musical instruments." 24 Harich-Schneider states additionally that "during the first years of the seventeenth century the making of musical instruments was in full swing. The earliest Japanese-made European instruments were portable bamboo organs." 25 It is not impossible that Santa Marta constructed organs with bamboo pipes in the Philippines, perhaps initiating a tradition that in any case culminated in the construction of the famous Bamboo Organ of Las Piñas.

References to keyboard instruments in Manila are scattered throughout documents from the seventeenth century. An early example of the secular use of organs in the seventeenth century is found in an account of the triumphant entry into Manila on 7 June 1637 by Governor Sebastián Hurtado de Corcuera, after his military victories in the southern island of Mindanao. This recounts that "the procession was enlivened by a great variety of dances and similar exhibitions, accompanied by various musical instruments and two portable organs." 26 Similar evidence from elsewhere in the empire suggests that such instruments were "regal [organs], portable and loud enough to be taken outside for processions and sacred plays." 27

Organ music was an important part of public celebration, and the Jesuit Pedro Murillo Velarde mentioned in his Historia de la Provincia de Philipinas de la Compañía de Jesús (Manila, 1749) that in 1621, a Japanese organist performed in the festivities surrounding the beatification of St. Francis Xavier.

Concurriò à la celebridad de estas fiestas un Clerigo Iapon organista, y musico, que en honra, y agradecimiento à su Santo Apostol, hizo varias composiciones de buen gusto. ${ }^{28}$

To the fame of these festivities was joined a Japanese cleric, who was a musician and organist, in honour of and gratitude to his holy apostle, played various compositions of good taste.

23. Lucrecia Kasilag, "Philippines," The New Grove Dictionary of Music and Musicians, ed. Stanley Sadie, 2nd ed., vol. 19 (London: Macmillan, 2000) 581-2; Ma Concepción Echevarría Carril, "La música franciscana en Filipinas (ss. XVI-XIX)," Nassarre IX.2 (1993): 200.

24. Quoted in Harich-Schneider, 474.

25. Ibid.

26. Letter by Fr. Juan Lopez in Emma H. Blair and James A. Robertson, eds., The Philippine Islands, 1493-1898, 55 vols. (Cleveland: Arthur H. Clark Co., 1903-09), 27:337.

27. José-Antonio Guzmán-Bravo, "Mexico, home of the first musical instrument workshops in America," Early Music 6.3 (1978): 351.

28. Pedro Murillo Velarde, Historia de la Provincia de Philipinas de la Compañía de Jesús. Segunda parte, que comprehende los progresos de esta provincia desde el año de 1616 hasta el de 1716 (Manila: en la Imprenta de la Compañía de Jesús, por D. Nicolás de la Cruz Bagay, 1749), 16v. 
This could refer to Luis Shiozuka (1576-1637), a Japanese Jesuit who arrived in Manila in 1614, or the Augustinian Fray Guillermo de Silva y Cárdenas (d. 1647), a well-known organist who was born in Japan. According to biographers of the Augustinian order in the Philippines, Fray Guillermo de Silva y Cárdenas was born around about the turn of the seventeenth century in the Empire of Japan, but then professed and finished his studies in the Augustinian convent of Manila. ${ }^{29}$ He was a famous musician, and was for many years organist in the church of San Agustín, Manila, which implies the early presence of an organ there..$^{30}$ In this same church was a famous Tagalog musician, Marcelo de San Agustín (d. 1697), who was born in Malate, Extramuros, and became a brother of the Augustinian order on 5 September 1652. ${ }^{31}$ The historian Gaspar de San Agustín, O.S.A., referred to him in his Conquistas de las Islas Philipinas (1698).

Un Hermano tenèmos en la Religion, llamado Fray Marcelo de San Augustin, natural de este Puevlo, que puede ser corona de los Indios Tagàlos, por su rara virtud, y lo bien que ha servido al Convento de Manila, en varios oficios; para todos los quales le ha dado Dios habilidad. Porque èl es Organista el mas diestro que se conoce entre los Indios, que son muy habiles en Instrumentos; es Compositor, y Maestro de los Cantores, y Sacristan Menor, y ha hecho, y escrito muchos Libros de el Coro, y sobre todo, es gran Siervo de Dios. ${ }^{32}$

We have a brother in religion, called Brother Marcelo de San Agustín, native to this city, who could be the crown[ing glory] of the Tagalogs, for his rare virtue, and for the good service he has rendered to the Convent of Manila, in various capacities, all those for which God gave him ability. For he is the most dextrous organist known among the Indians, who are very skilful in playing instruments; he is a composer, and choirmaster, and minor sacristan, and has made and written many choirbooks, and above all, he is a great servant of God.

Many organists in the church of San Agustín have been identified. Several were non-European musicians, such as the lay Augustinian brother Juan de Alfaro (d. 1745), a Waray indio born in Tanauan, Leyte, who played in San Agustín for twenty years. ${ }^{33}$ During the occupation of Manila by British forces from 1762 to 1764, the Augustinians were expelled from their church and convent on November 3,1762, and one hundred men proceeded to sack the complex over fourteen days. The convent was returned to the order on 31 December 1763, and amongst the items listed as missing after the sacking were two realejos. ${ }^{34}$ Rather than carried away intact as war booty, it is more likely that

29. Manuel Merino, O.S.A., Agustinos Evangelizadores de Filipinas 1565-1965 (Madrid: 1965), 440; Elviro Jorge Pérez, Catálogo bio-bibliográfico de los religiosos Agustinos de la provincia del Santissimo Nombre de Jesús de las islas Filipinas desde su fundación hasta nuestros días (Manila: Establecimiento tip. del Colegio de Sto. Tomás, 1901), 195.

30. Pedro G. Galende, O.S.A. and José Regalado Trota, San Agustín: Art \& History 1571-2000 (Intramuros, Manila: San Agustín Museum, 2000), 138.

31. Gregorio de Santiago Vela, O.S.A., Ensayo de una Biblioteca Ibero-Americana de la Orden de San Agustín, 8 vols. (Madrid: Imp. Asilo de Huérfanos del S. C. de Jesús, 1913-1931), 7:131.

32. Gaspar de San Agustín, Conquistas de las Islas Philipinas: La Temporal, por las armas del Señor Don Phelipe Segundo el Prudente; y la Espiritual, por los Religiosos del Orden de Nuestro Padre San Augustin: Fundacion, y progressos de su provincia del Santissimo Nombre de Jesus (Madrid: Ruiz de Murga, 1698), 490.

33. Galende and Trota, 138.

34. Ibid., 48, 138. 
these were purloined by curio hunters or melted down for bullets. Other instruments must have been present in this church, however, as the organists Francisco Amperosa (d. 1771) and Felipe Capurul (d. 1781) were active there. The main organ in this church was built between the beginning and middle of the eighteenth century, and is the oldest and largest mechanical pipe organ known in the Philippines today. ${ }^{35}$ It deteriorated so much in the late eighteenth century that in 1810 , the Provincial of the order commissioned the organ to be rebuilt and improved, using its existing parts (see fig. 1). This work was completed in December $1813,{ }^{36}$ and the instrument remains the only organ in Intramuros to have survived the shelling of 1945. Recently restored, it currently takes pride of place in the San Agustín International Music Festival, which is held annually in November.

Fig. 1

Organ in the Augustinian Church of San Agustín, Intramuros, Manila. George A. Miller, Interesting Manila, 100.

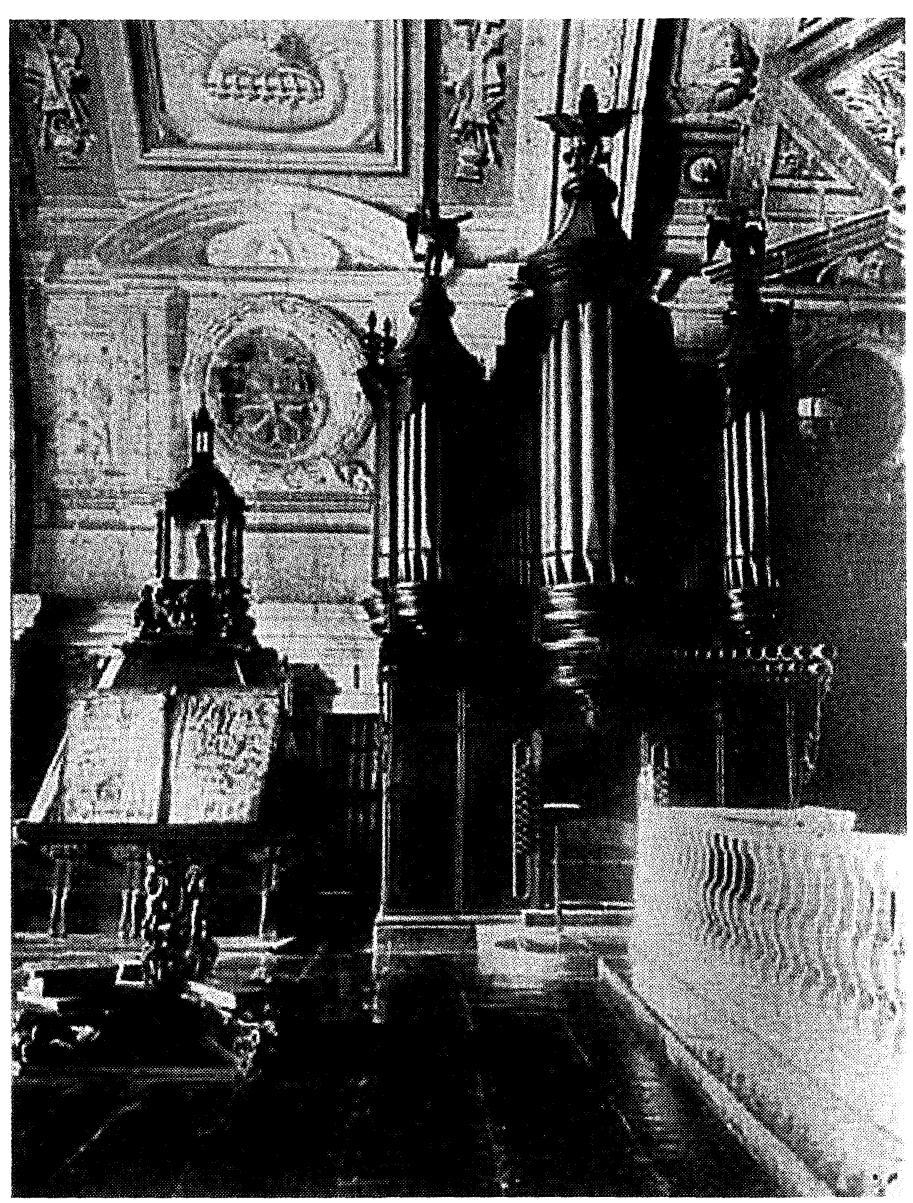

35. Hans Gerd Klais, "Philippinische Orgeln aus dem 18. und 19. Jahrhundert," Acta Organologica XIII (1979): 105-12, 121. It is likely, however, that this record will one day be eclipsed by new constructions from the Diego Cera Organbuilders in Las Piñas.

36. Galende and Trota, 138. 
The Augustinian order appears to have been prominent in the cultivation of organ music in Manila in the eighteenth century. In the first half of the century, a number of renowned organists and pedagogues arrived in the islands, making a significant contribution to keyboard music. The first such figure was Fr. Lorenzo Castelló, O.S.A. (1686-1743), originally preacher, confessor, cantor and organist in the Augustinian convent San Felipe el Real, Madrid. ${ }^{37}$ Arriving in 1718, he soon became known as the "Orfeo Agustino" as he exercised his musical prowess in Manila, and in the city of Cebu from 1722. Returning to Manila in 1732, he directed choirs, reformed choir books and wrote new ones. He taught music to more than two thousand Tagalog and Ilocano boys during his twenty-five-year mission in the islands, and was the composer of six manuscript volumes of classical masses, vespers, processions, villancicos and arias, ${ }^{38}$ although none of this music has surfaced in post-war Manila.

Another renowned musician from San Felipe el Real, Juan Bolívar, O.S.A. (1708-1754), arrived in Manila in 1739. He was a famous singer and instrumentalist, and had been solicited by the cathedrals of both Toledo and Mexico. ${ }^{39} \mathrm{He}$ played the organ, harp, violin, recorder and other instruments and was known for his incomparable timbre of voice. Before being stationed on the Visayan island of Panay, he was heavily involved in the cultivation of music in Manila, and composed three volumes of Glorias, Credos and villancicos, which are also unfortunately lost. ${ }^{40}$

Each major church and convent of Manila would have had one or more organs, but the dispersal of religious archives in the twentieth century has complicated the task of piecing together evidence of their construction, purchase and use. While most Jesuit archives were destroyed in 1945, the Augustinian and Franciscan archives were transferred to Europe before World War II, but the Archdiocesan, Dominican and Recollect archives remain more or less intact in Manila. ${ }^{41}$ To go through these records systematically is a colossal scholarly assignment which, when undertaken, may reveal much about those instruments that perished in 1945.

There are, nevertheless, some significant historical facts and vignettes from the mid-eighteenth century, concerning keyboard instruments and their practitioners. For example, in 1740, one Faustino Magsaisay, whose surname is Tagalog, was listed as organist in the Libro de Gobierno of Manila Cathedral. ${ }^{42}$ In an account of the celebration of the beatification of the Dominican saint Benedicto XI, held in Manila on 7 July 1741, there is evidence of the great esteem in which the new pipe organ was held in the church of Santo Domingo.

A hora competente de la tarde se cantaron unas Visperas solemnissimas; en las que la dulzura, y suavidad de los canoros Cisnes fuè cosa de encanto, y deleytable echizo del oido: tales fueron los quiebros, y trinados de sus sonoras gargantas, y tal la acordada consonancia, y dulce melodia de varios

37. Santiago Vela, 1:651-2

38. Ibid.

39. He appears in some Filipino music chronologies, such as Raymundo C. Bañas, Philipino Music and Theater (Quezon City: Manlapaz Publishing Company, 1969), under the name Marcelo de San Agustín, and should not be confused with the Tagalog musician of the same name.

40 Santiago Vela, 1:437.

41. Robert van Niel, A Survey of Historical Source Materials in Java and Manila, Asian studies at Hawaii; no. 5. (Honolulu: University of Hawaii Press, 1970), 245-55. 
instrumentos musicos, en especial del Organo maximo de los dos, que tiene nuestro Choro, admiracion de todos los que saben lo que hà costado, $\mathrm{y}$ lo que es! ${ }^{43}$

At the appropriate hour of the afternoon there were sung Solemn Vespers, in which the sweetness and suavity of the melodious singers was something charming, and delightful to the ear: such was the swaying and singing of their sonorous throats, and such the tuneful consonance, and sweet melody of various musical instruments; especially the great Organ of the two, contained in our Quire, [which is] the admiration of all who know what it cost, and what it is!

In the following year of 1742, there was established in Manila Cathedral the Colegio de Niños Tiples, in which boys were trained to become musicians and singers, with organ playing among the subjects taught. ${ }^{44}$

The high point in colonial instrument-building can be considered to have occurred in the final decade of the eighteenth century, after the arrival of the Recollect missionary Diego Cera de la Virgen del Carmen (1762-1832), on 5 June 1792.. ${ }^{45}$ A native of Graus, Huesca, Cera was a polymath, with skills as a scientist, chemist, engineer, artist, architect, musician, politician, agriculturalist and urban planner. ${ }^{46}$ Upon his arrival, Cera set out immediately to establish a workshop in which were constructed pipe organs and fortepianos. The first fortepiano he built there was regarded by the Governor-General of the Philippines, Don Rafael María de Aguilar y Ponce de León, as having have no equal in Spain or England, and being so beautiful that it would be a worthy gift to the queen. ${ }^{47}$ It is unknown, however, which were the qualities of the instrument that were so incomparable.

José de Santa Orosia, the Provincial of the Recollect order in the Philippines, confirmed this decision on 29 October 1793, and dedicated the fortepiano to Her Royal Highness, María Luisa de Borbón, wife of Carlos IV. ${ }^{48}$ As a token of gratitude on receving the instrument, the queen sent to Cera a church bell, and a chalice and cruets made from gold, ${ }^{49}$ which still exist today at St. Joseph's Church, Las Piñas, home of the famous Bamboo Organ. Francisco Salamero Reymundo, biographer of Cera, ${ }^{50}$ has searched for this fortepiano in the Patrimonio Nacional, Palacio de Oriente, La Granja, and the

42. Summers, "Listening for Historic Manila," 226. Original reference from the Archdiocesan Archives of Manila, Libro de Gobierno, December 15, 1740, number 296.

43. Diego Saenz, O.P., Festivas Expressiones, Aplausos Celebres, y Sagrados Triumphos, con que la Santa Provincia del Smo. Rosario de las Islas Philipinas celebró la Beatificacion del nuevo Astro Dominico. San Benedicto XI. en el Convento de N. P. S. Domingo de la Ciudad de Manila, el dia 7. de Julio del año de 1741 (Sampaloc, Manila: Convento de Nra. Señora de Loreto, 1742), 23. Biblioteca Nacional de España, R/33365.

44. Blair and Robertson, eds., 45:244-5; Summers, "Listening for Historic Manila," 216.

45. Samson, 26-8.

46. Alex R. Castro, Mission and Music: Padre Diego Cera in Mabalacat, 2002, Internet. Originally published in Sun*Star Pampanga, Available: http://www.geocities.com/balen_net/alex09.htm, 24 June 2003.

47. Samson, 29; Summers, "Listening for Historic Manila," 230-1.

48. Summers, "Listening for Historic Manila," 230-1; Enrique Cantel Cainglet, "Hispanic Influences on the West Visayan Folk Song Tradition of the Philippines," Unpublished Ph.D. Thesis, University of Adelaide, 1981, 412.

49. Cealwyn Tagle, The Builder: P. Fray Diego Cera de la Virgen del Carmen, Internet, http://bamboo.diegocera.com/ the_builder.htm, 14 Sept. 2003.

50. See Francisco Salamero Reymundo, Ensayo biográfico sobre Diego Cera: un grausino universal (Huesca: Diputación provincial, 1987). 
Asociaciones Musicales de Madrid, but as yet to no avail. ${ }^{51}$ It is possible that this instrument could exist in another Spanish city, however.

Cera was soon commissioned to build a monumental organ for the church of his order in Intramuros, San Nicolás Tolentino. Supervising the building whilst being stationed in the nearby towns of Mabalacat (Pampanga province) and Las Piñas (Rizal province), this intrument was completed in 1798. The organ reputedly had thirty-three stops, among which was one made of bamboo. ${ }^{52}$ This was probably his ground for experimenting with the performance and durability of this wood, ${ }^{53}$ before later commencing his most humble yet most enduring work, in constructing the organ of Las Piñas from 1816 to 1821 with 747 speaking bamboo pipes and 129 metal pipes. $^{54}$

The organ in San Nicolás Tolentino was damaged in 1898 by Spanish troops quartered there during the siege of Manila, and the entire Recollect church and convent were destroyed in 1945. The memory of what was probably the largest instrument built by Cera has been preserved, however, in a photograph (fig. 2) and an extensive description made in 1906 by the American Methodist Episcopalian missionary George Miller.

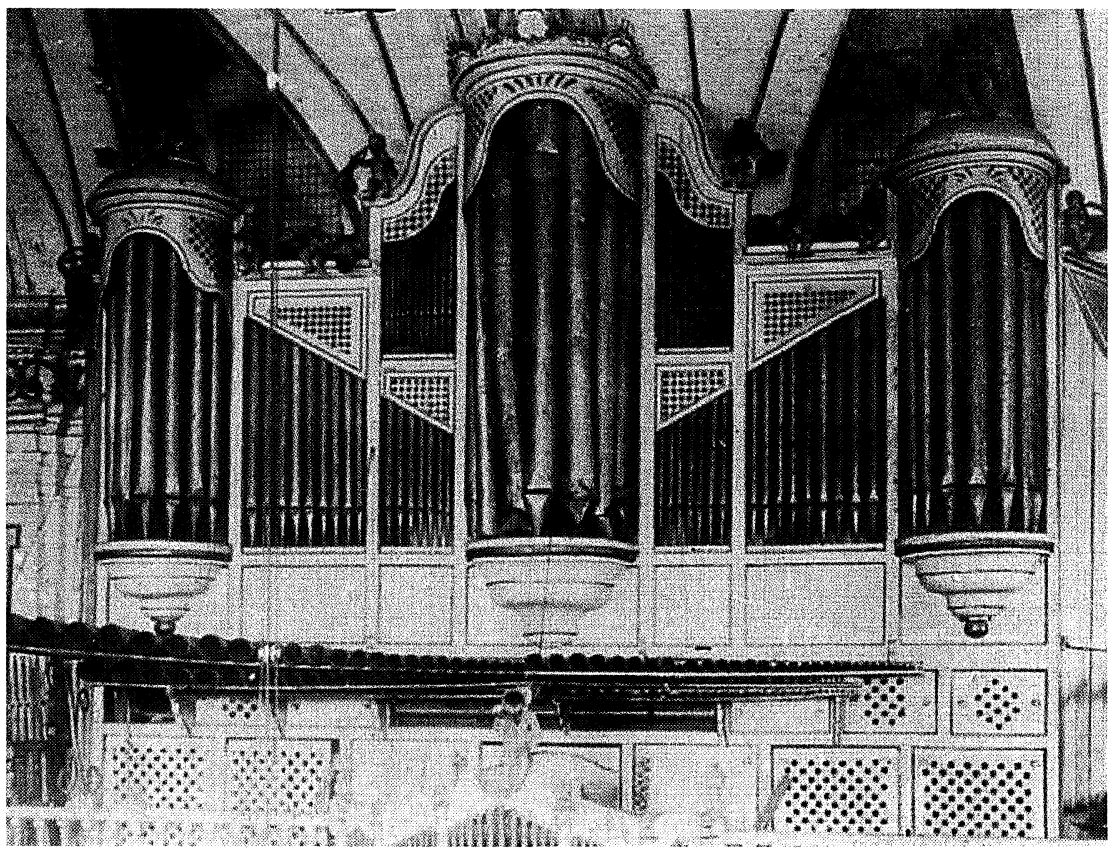

Fig. 2

Organ in the Recollect Church of San Nicolás Tolentino, Intramuros, Manila.

George A. Miller, Interesting Manila, 102.

51. Francisco Salamero Reymundo, Fray Diego Cera, un Grausino Universal, March/April 2001, Internet, Available: http://www.ribagorza.com/personajes/cera.htm.

52. Tagle; Waterhouse, 365; Samson, 29.

53. Samson, 29.

54. Ibid., 65 . 
[Cera's] masterpiece still stands in the Recoletos church of Manila and may some time be repaired for further use.

Like 'the harp that once through Tara's halls the soul of music shed,' it now hangs mute on the high church walls, silent in its narrow side gallery on the right of the nave. Its keys are brown and broken, its stops have few names left to tell what was to be expected when they were drawn, and age and decay are written all over its old case. The big diapasons in front have crushed with their own weight till they stand mute and broken witnesses to the march of time. There is something pathetic about those drooping pipes. They are bowed in weeping that they can no longer sing to the glory of God; the organ is dead, and its soul has fled to join the spirits that help swell the music of the spheres. But there is both music and poetry in the silence of the old pipes and yellow keys; 'the silent organ loudest chants the master's requiem.'

In its original form the organ was a remarkable construction. It has always stood in its present position in the south gallery of the nave, but as first built there were a number of figures of angels scattered about the cornice of the church, each of them holding to its lips a trumpet. The trumpet pipes were connected with the main organ by tubes, and any or all of them could be sounded at the will of the player. The effect of the tones coming from all over the church is said to have been most striking. In fact it is claimed that the worshipers were so distracted by the unusual sounds from strange places that the use of the scattered trumpeters was after fifty years discontinued and the organ reduced to its present form and position.

The pipes are arranged in most peculiar fashion in groups scattered about the interior of the space ranged along the wall. The sixteen-foot pedal bourdon is reinforced by a set of wooden reed pipes of conical form, and way up above the chest is a box thick with pipes a foot long and less, like a veritable pandora's box of whistles.

Back of the player's seat and forming the front of the gallery is the great organ with its huge horizontal reeds. These reeds, as all the others in the organ, have no independent pipes for the foot, but are placed in rows stuck into holes bored in long pieces of wood. The case is cracked, the keys are broken and the stop-knobs are nameless and yellow. There are some forty of these knobs and the organ contained about a thousand pipes when in good order.

What the tooth of time and the wear and tear of constant usage could not do was reserved for the Spanish soldiers in 1898 when they were quartered in the church during the siege. With profane hands they tore out the pipes, broke the keys and defaced the noble old organ so that it has never spoken since. The action is well made and might be easily rebuilt, but there is no hurry. The Order has filed a claim with the United States government for eight hundred pesos for damage done during the insurrection by Spanish soldiers. When this is paid the organ will be rebuilt, and then, the courteous guardian of the temple informed me they would send for me that I might know the pleasure of playing the organ with such a history. This I would count a rare treat, but under the above conditions I am not making any dates for the event. ${ }^{55}$

On 5 November 1795, Diego Cera repaired to Las Piñas, approximately $40 \mathrm{~km}$. to the south of Intramuros. He presumably continued his direction of organ construction from this town, and it was possibly his workshop that undertook the rebuilding of the organ in San Agustín, completed in 1813. The influence of Cera was undoubtedly felt throughout the archipelago; for example, in the island province of Bohol, which was allocated to the Recollect order on the expulsion of the Jesuits in

55. Miller, 99-104. 
1768 , there were at least eleven pipe organs at the end of the nineteenth century. ${ }^{56}$ This is the highest known number of pipe organs in any province in the country (outside of Manila). ${ }^{57}$ It is perhaps no surprise that similarities have been noted between the tripartite construction of these organs and those known to have been built by Cera in Manila. The legacy of Cera remains strong; a new organbuilding firm based in Las Piñas and bearing his name ${ }^{58}$ has been responsible for the fine restoration of numerous surviving instruments and the construction of mechanical tracker organs. The indelible cultural imprint left by Spain in the Philippines is well evident in the culture of organ-playing and sacred music, as well as in the realm of pianoforte performance. It is hoped that this brief study will serve to open new avenues of research in the area of historical keyboard instruments in South-East Asia.

\section{References}

Bañas, Raymundo C. Philipino Music and Theater. Originally published as The Music and Theater of the Filipino People. Manila: By the author, 1924. Quezon City: Manlapaz Publishing Company, 1969.

Blair, Emma H., and James A. Robertson, eds. The Philippine Islands, 1493-1898. 55 vols. Cleveland: Arthur H. Clark Co., 1903-09.

Cainglet, Enrique Cantel. "Hispanic Influences on the West Visayan Folk Song Tradition of the Philippines.” Unpublished Ph.D. Thesis. University of Adelaide, 1981.

Castleton, Robert William Harold. "The Life and Works of Domingo de Salazar, O.P. (1512-1594)." Unpublished Ph.D. Thesis. University of London, 1974.

Castro, Alex R. Mission and Music: Padre Diego Cera in Mabalacat. 2002. Internet. Originally published in Sun*Star Pampanga. Available: http://www.geocities.com/balen_net/alex09.htm. 24 June 2003.

Echevarría Carril, M Concepción. "La música franciscana en Filipinas (ss. XVI-XIX).” Nassarre IX.2 (1993): 197-210.

Galende, Pedro G., O.S.A., and Trota, José Regalado. San Agustín: Art \& History 1571-2000. Intramuros, Manila: San Agustín Museum, 2000.

Gómez Platero, Eusebio. Catálogo Biográfico de los Religiosos Franciscanos de la Provincia de San Gregorio Magno de Filipinas desde 1577 en que llegaron los primeros á Manila hasta los de nuestros días. Manila: Imprenta del Real Colegio de Santo Tomás, á cargo de D. Gervasio Memije, 1880.

56. Regalado Trota José, "Music-making in old Bohol: Notes from three Bohol parish archives," Bulawan: Journal of Philippine Arts \& Culture 1 (2001): 93-4.

57. Ibid., 94.

58. Diego Cera Organbuilders was founded in 1994 by Cealwyn Tagle and the late Edgar Montiano, who studied their craft in Austria. Their website is located at http://www.diegocera.com. They have a number of apprentices, some of whom have had experience with firms in Spain.

38

(c) Consejo Superior de Investigaciones Científicas Licencia Creative Commons 3.0 España (by-nc)
Anuario Musical, 60 (2005)

http://anuariomusical.revistas.csic.es 
Guzmán-Bravo, José-Antonio. "Mexico, home of the first musical instrument workshops in America." Early Music 6.3 (1978): 350-5.

Harich-Schneider, Eta. A History of Japanese Music. London: Oxford University Press, 1973.

Hernández, Vicente S. History of Books and Libraries in the Philippines: 1521-1900. Manila: The National Commission for Culture and the Arts, 1996.

Kasilag, Lucrecia. "Philippines." The New Grove Dictionary of Music and Musicians. Ed. Stanley Sadie. 2nd ed. Vol. 19. London: Macmillan, 2000. 581-2.

Klais, Hans Gerd. "Philippinische Orgeln aus dem 18. und 19. Jahrhundert." Acta Organologica XIII (1979): 75-123.

Klais, Hans Gerd, and Hans Steinhaus. The Bamboo Organ in the Catholic Parish Church of St. Joseph at Las Piñas, Province of Rizal on the Island of Luzon, Philippines. Trans. Homer D. Blanchard. Delaware, Ohio: Praestant Press, 1977.

Lindorff, Joyce Z. "The Harpsichord and Clavichord in China during the Ming and Qing Dynasties." Early Keyboard Studies Newsletter VIII.4 (1994): 1-8.

Merino Antolínez, Jesús Ma , O.P. "San Pedro Bautista: Philippine Benefactor." San Pedro Bautista: A Saint in the Philippines. Quezon City: Devotees of San Pedro Bautista, 1982.

Merino, Manuel, O.S.A. Agustinos Evangelizadores de Filipinas 1565-1965. Madrid, 1965.

Miller, George A. Interesting Manila. 2nd ed. Manila: E. C. McCullough \& Co., Inc., 1906.

Morga, Antonio de. Sucesos de las Islas Filipinas. Mexico, 1609. Trans. J. S. Cummins. Works issued by the Hakluyt Society; 2nd series, no. 140. Cambridge: Cambridge University Press, 1971.

Murillo Velarde, Pedro. Historia de la Provincia de Philipinas de la Compañía de Jesús. Segunda parte, que comprehende los progresos de esta provincia desde el año de 1616 hasta el de 1716. Manila: en la Imprenta de la Compañía de Jesús, por D. Nicolás de la Cruz Bagay, 1749.

Niel, Robert van. A Survey of Historical Source Materials in Java and Manila. Asian studies at Hawaii; no. 5. Honolulu: University of Hawaii Press, 1970.

Pérez, Elviro Jorge. Catálogo bio-bibliográfico de los religiosos Agustinos de la provincia del Santissimo Nombre de Jesús de las islas Filipinas desde su fundación hasta nuestros días. Manila: Establecimiento tip. del Colegio de Sto. Tomás, 1901.

Saenz, Diego, O.P. Festivas Expressiones, Aplausos Celebres, y Sagrados Triumphos, con que la Santa Provincia del Smo. Rosario de las Islas Philipinas celebró la Beatificacion del nuevo Astro Dominico. San Benedicto XI. en el Convento de N. P. S. Domingo de la Ciudad de Manila, el dia 7. de Julio del año de 1741. Sampaloc, Manila: Convento de Nra. Señora de Loreto, 1742.

Salamero Reymundo, Francisco. Ensayo biográfico sobre Diego Cera: un grausino universal. Huesca: Diputación provincial, 1987.

-. Fray Diego Cera, un Grausino Universal. March/April 2001. Internet. Available: http://www. ribagorza.com/personajes/cera.htm.

Salazar, Domingo de, O.P. "Erection of the Manila Cathedral." The Philippine Islands, 1493-1898. Ed. James A. Robertson. Vol. 34. Cleveland: Arthur H. Clark Co., 1903-09. 332-60.

Samson, Helen F. The Bamboo Organ of Las Piñas. Las Piñas: Parish of St. Joseph, 1977. 
San Agustín, Gaspar de. Conquistas de las Islas Philipinas: La Temporal, por las armas del Señor Don Phelipe Segundo el Prudente; y la Espiritual, por los Religiosos del Orden de Nuestro Padre San Augustin: Fundacion, y progressos de su provincia del Santissimo Nombre de Jesus. Madrid: Ruiz de Murga, 1698.

Santiago Vela, Gregorio de, O.S.A. Ensayo de una Biblioteca Ibero-Americana de la Orden de San Agustín. 8 vols. Madrid: Imp. Asilo de Huérfanos del S. C. de Jesús, 1913-1931.

Summers, William John. "The Jesuits in Manila, 1581-1621: The Role of Music in Rite, Ritual and Spectacle." The Jesuits: Culture, Learning and the Arts, 1540-1773. Ed. John W. O'Malley. Toronto: University of Toronto Press, 1999. 659-79.

-. "Listening for Historic Manila: Music and Rejoicing in an International City." Budhi: A Journal of Ideas and Culture 2.1 (1998): 203-54.

Tagle, Cealwyn. The Builder: P. Fray Diego Cera de la Virgen del Carmen. Internet. http://bamboo. diegocera.com/the_builder.htm. 14 Sept. 2003.

Trota, José Regalado. "Music-making in old Bohol: Notes from three Bohol parish archives." Bulawan: Journal of Philippine Arts \& Culture 1 (2001): 92-107.

Villarroel, Fidel, O.P. "Implications of the Religious Festival in Intramuros." Intramuros and Beyond. Manila: Letran College, 1975.

Waterhouse, David B. "Southern Barbarian Music in Japan." Portugal and the World: The Encounter of Cultures in Music. Ed. Salwa El-Shawan Castelo-Branco. Lisbon: Publicações Dom Quixote, 1997. 351-77.

Woodfield, Ian. "The Keyboard Recital in Oriental Diplomacy, 1520-1620." Journal of the Royal Musical Association 115.1 (1990): 33-62. 